\title{
Analisis Pendapatan dan Faktor-Faktor Yang Mempengaruhi Penerapan System of Rice Intensification (Sri) Di Desa Trasan Kecamatan Bandongan Kabupaten Magelang
}

\author{
Income and Affecting Factors Analysis of System Rice of Intensification (SRI) \\ Application in Trasan Village Bandongan Subdistrict Magelang District \\ Yulisa Andriani Ginting ${ }^{1)}$ \\ Leo Rio Ependi Malau ${ }^{2}$ \\ ${ }^{1)}$ PT. BPD Djakarta Raya (Bank DKI), Tangerang Selatan, Banten, Jawa Barat, Indonesia \\ ${ }^{2)}$ Balitbang Lingkungan Hidup dan Kehutanan Palembang, Sumatera Selatan, Indonesia \\ Email: andrianiyulisa1@gmail.com ${ }^{1)}$ \\ Penulis korespondensi: leoriomalau62@gmail.com ${ }^{2)}$
}

\begin{abstract}
System of Rice Intensification (SRI) is one of technology to improve paddy productivity. SRI was introduced in 2009 but have not applied by all farmers. This study aimed to analyze cost structure, revenue and income of paddy farming with and without SRI method, and to identify affecting factors in applying SRI method. This research was conducted in Trasan Village, Bandongan, Magelang District. Respondents for this study were farmers who applied and have not applied SRI, 30 persons each. Data were analyzed using $R / C$ ratio and binary logit. The results showed that SRI method more profitable than non SRI due to increased in paddy productivity that affect farm revenue and income. However, the total cost of the SRI method is greater than the non SRI method due to the increased use of labour and organic fertilizers. Affecting factors in application SRI method are age, farming experience, education, farming orientation, land area, productivity and farming income.
\end{abstract}

Keywords: binary logit, cost structure, revenue, system of rice intensification (SRI).

\begin{abstract}
ABSTRAK
System of Rice Intensification (SRI) merupakan salah satu teknologi dalam meningkatkan produktivitas padi. SRI mulai diperkenalkan pada tahun 2009 namun belum diterapkan oleh seluruh petani. Penelitian ini bertujuan untuk menganalisis struktur biaya, penerimaan dan pendapatan usahatani metode SRI dan non SRI dan mengindentifikasi faktor-faktor yang mempengaruhi penerapan metode SRI. Penelitian ini dilakukan di Desa Trasan, Kecamatan Bandongan, Kabupaten Magelang. Responden dalam penelitian ini adalah petani yang menerapkan SRI dan tidak menerapkan SRI dengan jumlah masing-masing 30 petani. Data dianalisis menggunakan $\mathrm{R} / \mathrm{C}$ rasio dan regresi logistik. Hasil penelitian menunjukkan metode SRI lebih menguntungkan dibandingkan non SRI karena peningkatan produkivitas padi sehingga berpengaruh terhadap penerimaan dan pendapatan usahatani. Namun total biaya metode SRI lebih besar dibandingkan non SRI karena peningkatan penggunaan tenaga kerja dan pupuk
\end{abstract}


organik. Faktor-faktor yang mempengaruhi penerapan metode SRI adalah usia, pengalaman usahatani, tingkat pendidikan, status usahatani, luas lahan garapan, produktivitas dan pendapatan usahatani.

Kata kunci: binary logit, penerimaan, system rice of intensification (SRI),struktur biaya.

\section{PENDAHULUAN}

Beras merupakan pangan pokok mayoritas penduduk Indonesia. Seiring dengan meningkatnya jumlah penduduk dengan tingkat rata-rata konsumsi beras per kapita yang masih tinggi maka kebutuhan beras dimasa yang akan datang diperkirakan akan meningkat. Namun dalam beberapa tahun terakhir produktivitas padi sawah hampir maksimum mendekati leveling off (Kusnadi, et al., 2011) dan diduga akan berdampak pada menurunnya penyediaan stok pangan dan keamanan pangan nasional. Oleh karena itu peningkatan produksi padi mutlak dilakukan dalam rangka menjaga ketersediaan pangan nasional.

Upaya meningkatkan produksi padi dapat ditempuh melalui program ekstensifikasi dan intensifikasi (perbaikan teknologi). Upaya meningkatkan produksi padi melalui perluasan areal tanam lebih sulit dilakukan karena banyaknya alih fungi lahan pertanian menjadi lahan non pertanian. Lebih lanjut Kusnadi, et al., (2011) menyatakan bahwa upaya ekstensifikasi semakin tidak efisien. Dengan demikian peningkatan produksi padi sebaiknya diarahkan kepada program intensifikasi yaitu memperbaiki teknologi anjuran yang diharapkan akan berdampak pada peningkatan produksi. Salah satu program intensifikasi yang berkembang di Indonesia adalah System of Rice Intensification (SRI).

System of Rice Intensification (SRI) merupakan "salah satu pendekatan dalam praktik budidaya padi yang menekankan pada manajemen pengelolaan tanah, tanaman dan air melalui pemberdayaan kelompok dan kearifan lokal yang berbasis pada kegiatan ramah lingkungan" (Anugrah, et al., 2008). Metode ini berfokus pada upaya perbaikan tingkat keseburuan tanah dan produktivitas padi akibat penggunaan pupuk dan pestisida kimia yang massif. Pirngadi (2009) melaporkan bahwa metode SRI terbukti mampu meningkatkan produktivitas padi menjadi sebesar 8 Ton/Ha atau jauh lebih tinggi dibandingkan rata-rata produktivitas padi nasional.

Salah satu sentra produksi padi yang telah menerapkan SRI adalah Kabupaten Magelang melalui program "Magelang Go Organic" dengan beberapa kecamatan sentra produksi seperti kecamatan Secang, Grabag, Bandongan, Kajoran, Salaman dan Sawangan. Kecamatan Bandongan merupakan daerah dengan produktivitas padi tertinggi dibandingkan kecamatan lainnya dalam rentang waktu tahun 2011-2014 (BPS 2015). Peningkatan produktivitas tersebut didukung oleh penerapan SRI oleh petani melalui penyuluhan yang sudah dilakukan sejak tahun 2007. Kecamatan Bandongan terdiri dari 14 Desa dengan Desa Trasan sebagai Desa dengan produktivitas padi tertinggi serta telah mendapatkan penyuluhan metode SRI. Kegiatan penyuluhan metode SRI dilakukan oleh penyuluh maupun swadaya oleh petani sejak tahun 2009. 
Usahatani padi telah menjadi budaya dan diusahakan lintas generasi oleh petani desa Trasan. Usahatani padi dilakukan dengan metode SRI dan non SRI. Penggunaan metode usahatani padi yang berbeda memiliki konsekuensi terhadap perbedaan penggunaan input dan produksi yang dihasilkan. Input yang digunakan pada budidaya padi metode SRI dan non SRI di Desa Trasan berbeda baik dalam jenis maupun jumlahnya. Penggunaan jumlah pupuk organik dalam jumlah besar pada metode SRI akan meningkatkan biaya usahatani. Meningkatnya jumlah penggunaan pupuk organik disertai dengan penurunan penggunaan pupuk anorganik sehingga akan menurunkan biaya usahatani. Selain itu, penerapan prinsip lainnya akan menyebabkan perbedaan penggunaan input sehingga berpengaruh terhadap struktur biaya usahatani. Penerapan SRI juga berdampak terhadap perbedaan produktivitas sehingga menyebabkan perbedaan penerimaan. Perbedaan biaya dan penerimaan usahatani tersebut akan berdampak pada pendapatan usahatani padi.

Beberapa penelitian menyimpulkan bahwa penerapan metode SRI lebih hemat biaya dan menghasilkan produksi lebih besar sehingga pendapatan juga menjadi lebih besar (Adrianto, et al., 2016; Saragih, 2011 dan Mulyaningsih, 2010). Penerapan metode SRI yang berdampak pada efisiensi penggunaan input seperti benih, penghematan air dan mendorong penggunaan pupuk organik menjadi alasan yang menarik banyak petani untuk menerapkan metode SRI (Wardana, et al., 2005). Namun faktanya menunjukkan bahwa jumlah petani yang menerapkan SRI di Desa Trasan relatif sedikit dibandingkan non SRI. Berdasarkan uraian diatas maka penelitian ini bertujuan untuk (1) menganalisis struktur biaya, penerimaan dan pendapatan usahatani padi SRI dan non SRI di Desa Trasan dan (2) mengidentifikasi faktor-faktor yang mempengaruhi petani dalam menerapkan SRI di Desa Trasan.

\section{METODOLOGI PENELITIAN}

Penelitian dilaksanakan di Desa Trasan, Kecamatan Bandongan, Kabupaten Magelang, Jawa Tengah yang ditentukan secara sengaja (purposive) dengan alasan bahwa Kabupaten Magelang adalah sentra pertanian padi organik dan memiliki produktivitas padi sawah diatas produktivitas padi Jawa Tengah. Desa Trasan dipilih karena memiliki poduktivitas tertinggi di Kecamatan Bandongan dan memiliki potensi dalam pengembangan usahatani padi SRI karena peningkatan luas lahan tanam dan masih terdapat banyak petani yang belum menerapkan SRI.

Penelitian ini menggunakan data primer yang dikumpulkan dengan wawancara terstruktur kepada petani berdasarkan panduan kuesioner. Data primer yang dikumpulkan antara lain: karakteristik sosial-ekonomi petani, keragaan usahatani, jenis, jumlah dan harga input serta output dan harga output. Sedangkan data sekunder yang dibutuhkan berupa data keragaan usahatani padi nasional yang dikumpulkan dari BPS, Kementan, buku, jurnal dan berbagai pustaka lainnya.

Sebanyak 60 petani dijadikan responden yang terdiri dari 30 petani yang menerapkan metode SRI dan 30 petani yang tidak menerapkan metode SRI. Penentuan jumlah sampel berdasarkan pertimbangan kecukupan data untuk dilakukan uji statistik. Teknik purposive sampling digunakan untuk menentukan responden berdasarkan saran dan 
arahan ketua kelompok tani (poktan) dan penyuluh Desa Trasan karena pihak tersebut yang mengetahui petani yang menerapkan dan tidak menerapkan metode SRI.

Data diolah dengan menggunakan analisis pendapatan usahatani dan regresi logistik (binary logit). Analisis usahatani terdiri dari analisis penerimaan, biaya, pendapatan dan $\mathrm{R} / \mathrm{C}$ rasio. Penerimaan usahatani dirumuskan sebagai berikut (Soekartawi, 2002):

$$
\mathrm{TR}=\mathrm{P} \times \mathrm{Q} \text {. }
$$

Keterangan:

$\mathrm{TR}=$ Penerimaan total usahatani $(\mathrm{Rp})$

$\mathrm{P} \quad=$ Harga jual gabah kering panen $(\mathrm{Rp} / \mathrm{kg})$

$\mathrm{Q} \quad=$ Jumlah gabah kering panen $(\mathrm{kg})$

Biaya usahatani dirumuskan sebagai berikut (Soekartawi et al., 2011):

$$
\mathrm{TC}=\mathrm{C}+\mathrm{NC}
$$

Keterangan:

$\mathrm{TC}=$ Total biaya $(\mathrm{Rp})$

$\mathrm{C}=$ Total biaya tunai $(\mathrm{Rp})$

$\mathrm{NC}=$ Total biaya non tunai $(\mathrm{Rp})$

Pendapatan usahatani dirumuskan sebagai berikut (Soekartawi 2002):

$\mathrm{Pd}$ atas total biaya $=\mathrm{TR}-\mathrm{TC}$.

$\mathrm{Pd}$ atas biaya tunai $=\mathrm{TR}-\mathrm{C}$.

$\mathrm{R} / \mathrm{C}$ rasio dirumuskan sebagai berikut (Soekartawi 2002):

$$
\begin{aligned}
& \mathrm{R} / \mathrm{C} \text { atas biaya tunai }=\frac{\text { Penerimaan usahatani }}{\text { Biaya tunai }} . \\
& \mathrm{R} / \mathrm{C} \text { atas total biaya }=\frac{\text { Penerimaan usahatani }}{\text { Total biaya }} . . .
\end{aligned}
$$

Selanjutnya, untuk menganalisis faktor-faktor yang memengaruhi penerapan SRI menggunakan regresi logistik biner (binary logit). Model regresi logistik yang digunakan dalam penelitian ini diadopsi dari Hosmer dan Lemeshow (2000) sebagai berikut:

$Y_{t}=\left(\ln \frac{y(x)}{1-v(x)}\right)=\beta_{0}+\beta_{1} X_{1 t}+\beta_{2} X_{2 t}+\beta_{3} X_{3 t}+\beta_{4} X_{4 t}+\beta_{5} X_{5 t}+\beta_{6} X_{6 t}++\beta_{7} X_{7 t}+{ }_{8} D_{8 t}+$ $\varepsilon t$

Dimana variabel dependen $\left(\mathrm{Y}_{\mathrm{t}}\right)$ merupakan variabel dummy penerapan metode SRI dengan (1) menerapkan SRI dan (0) tidak menerapkan SRI. $\beta_{0}$ adalah intersep atau konstanta, $\beta$ adalah parameter yang akan diestimasi dan $\varepsilon$ adalah variabel acak. Sedangkan variabel independen dalam penelitian ini yaitu usia ( $\mathrm{X}_{1}$ dalam satuan tahun), lama pendidikan formal ( $\mathrm{X}_{2}$ dalam satuan tahun), jumlah tanggungan keluarga $\left(\mathrm{X}_{3}\right.$ dalam satuan orang), pengalaman usahatani padi ( $\mathrm{X}_{4}$ dalam satuan tahun), luas lahan garapan ( $\mathrm{X}_{5}$ dalam satuan $\mathrm{Ha}$ ), produktivitas padi ( $\mathrm{X}_{5}$ dalam satuan $\left.\mathrm{Ton} / \mathrm{Ha}\right)$, pendapatan usahatani padi (Juta Rp/Ha) dan dummy status usahatani padi dengan (1) apabila merupakan usaha utama dan (0) apabila merupakan usaha sampingan. 


\section{HASIL DAN PEMBAHASAN}

\section{Struktur Biaya, Penerimaan dan Pendapatan Usahatani Padi SRI dan Non SRI}

Usahatani padi metode SRI dan non SRI memiliki perbedaan dalam penggunaan jenis dan jumlah input serta hasil panen (output) sehingga menyebabkan perbedaan biaya, penerimaan dan pendapatan yang diterima petani. Secara keseluruhan, total biaya metode SRI lebih besar dibandingkan non SRI (Tabel 1). Perbedaan tersebut disebabkan besarnya penggunaan tenaga kerja dan penggunaan pupuk organik dalam metode SRI. Hasil ini sesuai dengan penelitian Anugrah et al., (2011). Besarnya penggunaan tenaga kerja dalam metode SRI karena frekuensi beberapa kegiatan seperti penyiangan, pemupukan organik, pembuatan pupuk organik dan penyemprotan lebih sering dilakukan dibandingkan metode non SRI. Penggunaan metode SRI memang berdampak pada penghematan input produksi seperti benih dan pupuk anorganik namun dalam perawatannya membutuhkan lebih banyak tenaga kerja.

Berdasarkan analisis struktur biaya, komponen biaya terbesar adalah biaya bagi hasil dengan persentase sebesar $24,52 \%$ untuk metode SRI dan 49,35\% untuk metode non SRI. Biaya tersebut merupakan imbalan atas penggunaan lahan oleh petani penggarap dan dibayarkan kepada pemilik lahan. Ditinjau dari penggunaan input produksi, upah tenaga kerja menjadi komponen biaya terbesar dengan persentase sebesar 26,99\% untuk metode SRI dan $18,70 \%$ untuk metode non SRI. Gambaran penggunaan tenaga kerja ini berimplikasi bahwa metode SRI adalah usaha labour intensive atau banyak membutuhkan tenaga kerja.

Komponen biaya terbesar selanjutnya yaitu pupuk baik pupuk organik maupun anorganik. Metode SRI lebih banyak menggunakan pupuk organik dengan perbandingan $20,53 \%$ biaya pupuk organik dan $0,59 \%$ biaya pupuk anorganik. Sedangkan metode non SRI lebih banyak menggunakan pupuk anorganik dengan perbandingan 3,30\% biaya pupuk organik dan 3,99\% untuk pupuk anorganik. Besarnya penggunaan pupuk organik pada metode SRI bertujuan untuk memenuhi unsur-unsur hara pada tanah yang hilang pada saat musim tanam sebelumnya dan untuk menggemburkan tanah. Pupuk organik yang digunakan petani terdiri dari pupuk organik buatan pabrik, pupuk kandang dan buatan petani sendiri. Dalam praktik usahatani, petani dengan metode SRI masih menggunakan pupuk anorganik meskipun dalam persentase yang kecil. Hal ini disebabkan sulitnya memperoleh pupuk organik dan besarnya biaya penggunaan pupuk organik.

Biaya panen juga menjadi salah satu komponen biaya terbesar dengan persentase sebesar $13,37 \%$ untuk metode SRI dan 12,91\% untuk metode non SRI. Kegiatan panen di Desa Trasan menerapkan sistem pembagian hasil panen sebesar $10 \%$ kepada tenaga kerja 
panen sehingga kebutuhan tenaga kerja panen dibedakan dengan kebutuhan tenaga kerja pada kegiatan lain. Perbedaan persentase biaya panen karena perbedaan hasil panen dimana metode SRI menghasilkan produksi lebih besar dibandingkan non SRI. Sewa lahan juga menjadi salah satu fokus perhatian yang seringkali tidak diperhitungkan oleh petani. Bagi pemilik lahan sendiri, biaya ini tidak secara tunai dibayarkan sehingga seakan-akan keuntungan usahatani besar sedangkan pada petani penggarap biaya ini merupakan biaya tunai. Persentase biaya sewa lahan pada metode SRI sebesar 7,45\% dan pada metode non SRI sebesar 4,69\%.

Tabel 1. Rata-rata Biaya, Penerimaan dan Pendapatan Usahatani Padi/Ha/MT di Desa Trasan

\begin{tabular}{|c|c|c|c|c|c|}
\hline \multirow{2}{*}{\multicolumn{2}{|c|}{ Uraian }} & \multicolumn{2}{|c|}{ SRI $(n=30)$} & \multicolumn{2}{|c|}{ Non SRI $(n=30)$} \\
\hline & & Nilai (Rp) & $\%$ & Nilai (Rp) & $\%$ \\
\hline A. & Penerimaan & 26.932 .474 & 100 & 22.968 .611 & 100 \\
\hline B. & Biaya & & & & \\
\hline B. 1 & Biaya Tunai & & & & \\
\hline & Benih & 111.004 & 0,55 & 113.677 & 0,64 \\
\hline & Pupuk organik padat & 2.499 .766 & 12,41 & 443.056 & 2,49 \\
\hline & Pupuk organik cair & 960.365 & 4,77 & - & - \\
\hline & Pupuk urea & 21.613 & 0,11 & 318.675 & 1,79 \\
\hline & NPK Phonska & 96.439 & 0,48 & 390.767 & 2,20 \\
\hline & Pupuk lainnya & - & - & 1.167 & 0,01 \\
\hline & Dekomposer & 116.200 & 0,58 & 34.667 & 0,19 \\
\hline & Pestisida & - & - & 103.517 & 0,58 \\
\hline & Biaya bajak & 755.00 & 3,75 & 601.667 & 3,38 \\
\hline & TKLK & 2.415 .525 & 11,99 & 922.186 & 5,18 \\
\hline & Biaya panen & 2.693 .247 & 13,37 & 2.296 .861 & 12,91 \\
\hline & Bagi hasil & 4.940 .126 & 24,52 & 8.777 .639 & 49,35 \\
\hline & Pajak lahan & 20.717 & 0,10 & 5.667 & 0,03 \\
\hline & Karung & 181.610 & 0,90 & 194.917 & 1,10 \\
\hline & Total Biaya Tunai & 14.811 .612 & 73,53 & 14.204 .449 & 79,86 \\
\hline B. 2 & Biaya Non Tunai & & & & \\
\hline & Benih & 25.654 & 0,13 & 133,072 & 0,75 \\
\hline & Pupuk organik padat & 140.000 & 0,69 & 144.667 & 0,81 \\
\hline & Pupuk organik cair & 535.771 & 2,66 & - & - \\
\hline & TKDK & 3.020 .949 & 15,00 & 2.405 .278 & 13,52 \\
\hline & Sewa lahan & 1.500 .000 & 7,45 & 833.333 & 4,69 \\
\hline & Penyusutan & 110.122 & 0,55 & 65.445 & 0,37 \\
\hline & Total Biaya Non Tunai & 5.332 .496 & 26,47 & 3.581 .796 & 20,14 \\
\hline & Total Biaya & 20.144 .108 & 100 & 17.786 .244 & 100 \\
\hline C. & Pendapatan atas biaya tunai & 12.120 .862 & & 8.764 .162 & \\
\hline D. & Pendapatan atas total biaya & 6.788 .366 & & 5.182 .367 & \\
\hline E. & $\mathrm{R} / \mathrm{C}$ atas biaya tunai & 2,20 & & 2,04 & \\
\hline F. & $\mathrm{R} / \mathrm{C}$ atas total biaya & 1,42 & & 1,40 & \\
\hline
\end{tabular}

Sumber: Data primer (diolah) 
Penerapan SRI berdampak pada penghematan benih seperti terbukti dalam penelitian ini. Persentase biaya benih sebesar $0,68 \%$ untuk metode SRI dan $1,39 \%$ untuk metode non SRI. Hasil penelitian ini sejalan dengan temuan Adrianto, et al., (2016) yang menyatakan bawa penerapan SRI menghemat pengeluaran benih karena jumlah bibit per lubang tanam lebih sedikit dibandingkan non SRI. Komponen biaya selanjutnya yang penting untuk diperhatikan yaitu biaya bajak lahan. Pembajakan lahan di Desa Trasan menggunakan mesin traktor, tenaga ternak kerbau dan tenaga kerja manusia menggunakan cangkul tergantung pada kondisi tanah. Persentase biaya bajak lahan sebesar 3,75\% untuk metode SRI dan 3,38\% untuk metode non SRI.

Rata-rata biaya usahatani padi metode SRI sebesar Rp 20.144.108/Ha/MT dengan persentase biaya tunai sebesar $73,53 \%$ dan biaya non tunai sebesar $26,47 \%$. Sedangkan total biaya usahatani padi metode non SRI sebesar Rp 17.786.244/Ha/MT dengan persentase biaya tunai sebesar $79,86 \%$ dan biaya non tunai sebesar $20,14 \%$. Menarik untuk diperhatikan bahwa struktur biaya non tunai metode SRI lebih besar dibandingkan non SRI. Hal ini disebabkan penurunan penggunaan benih, pupuk anorganik dan pestisida dikompensasi dengan peningkatan penggunaan tenaga kerja dalam keluarga terutama dibutuhkan untuk perawatan tanaman dan pembuatan pupuk organik.

Penerapan metode SRI diharapkan dapat meningkatkan produksi seperti dibuktikan oleh penelitian Adrianto, et al., (2016); Erwinata, et al., (2013) dan Kurniadiningsih (2011). Hasil penelitian ini memperkuat temuan penelitian tersebut dengan rata-rata produksi padi metode SRI sebesar $6.243 \mathrm{Kg} / \mathrm{Ha} / \mathrm{MT}$ sedangkan metode non SRI menghasilkan produksi lebih kecil yaitu sebesar $5.577 \mathrm{Kg} / \mathrm{Ha} / \mathrm{MT}$. Rata-rata penerimaan usahatani metode SRI sebesar Rp 26.932.474/Ha/MT sedangkan metode non SRI sebesar Rp 22.968.611/Ha/MT.

Perbedaan biaya dan penerimaan selanjutnya akan menyebabkan perbedaan pendapatan usahatani. Rata-rata pendapatan usahatani dengan metode SRI lebih besar dibandingkan metode non SRI. Hasil ini sesuai dengan penelitian Kurniadiningsih (2012) dan Adrianto, et al., (2016) yang menyatakan bahwa petani yang menerapkan inovasi dalam kegiatan usahataninya menghasilkan keuntungan yang lebih lebih besar. Perbedaan pendapatan disebabkan oleh perbedaan penerimaan dan biaya usahatani. Pada usahatani yang menerapkan inovasi akan berdampak terhadap peningkatan biaya karena pembelian benih bermutu dan penggunaan tenaga kerja yang lebih intensif. Rata-rata pendapatan usahatani metode SRI sebesar Rp 12.120.862/Ha/MT atas biaya tunai dan Rp 6.788.366/Ha/MT atas total biaya. Sedangkan pada usahatani metode non SRI sebesar Rp17.786.244/Ha/MT atas biaya tunai dan Rp 5.182.367/Ha/MT atas total biaya.

Ditinjau dari $\mathrm{R} / \mathrm{C}$ rasio, usahatani yang menerapkan metode SRI menghasilkan $\mathrm{R} / \mathrm{C}$ rasio yang lebih besar dibandingkan metode non SRI. Rata-rata nilai R/C rasio metode SRI sebesar 2,20 atas biaya tunai dan 1,42 atas total biaya. Sedangkan R/C rasio metode non SRI sebesar 2,04 atas biaya tunai dan 1,40 atas total biaya. Hasil ini mengindikasikan bahwa metode SRI menghasilkan imbalan yang lebih besar atas setiap biaya yang dikeluarkan dibandingkan dengan metode non SRI. Hasil ini sesuai dengan Adrianto et al., (2016) dan Kurniadiningsih (2012) yang membuktikan bahwa usahatani padi yang 
menerapkan inovasi memiliki nilai $\mathrm{R} / \mathrm{C}$ rasio lebih besar dibandingkan usahatani yang tidak menerapkan inovasi.

Analisis yang telah diuraikan sebelumnya menunjukkan bahwa produktivitas, pendapatan dan $\mathrm{R} / \mathrm{C}$ rasio usahatani padi metode SRI lebih besar dibandingkan non SRI. Untuk melihat perbedaannya secara statistik maka digunakan uji beda Mann-Whitney. Berdasarkan hasil uji beda Mann-Whitney pada Tabel 2, rata-rata produktivitas metode SRI dan non SRI berbeda nyata pada $\alpha=5 \%$ sedangkan rata-rata pendapatan metode SRI dan non SRI berbeda nyata $\alpha=20 \%$. Berdasarkan hasil tersebut dapat disimpulkan bahwa penerapan metode SRI menghasilkan produktivitas dan pendapatan yang lebih besar dibandingkan metode non SRI.

Tabel 2. Hasil Uji Beda Produktivitas, Pendapatan dan R/C Rasio Usahatani Padi di Desa Trasan

\begin{tabular}{lrrr}
\hline \multirow{2}{*}{ Uraian } & \multicolumn{2}{c}{ Mean rank } & \multicolumn{2}{c}{$\begin{array}{c}\text { Asymp. Sig. } \\
\text { (2-tailed) }\end{array}$} \\
\cline { 2 - 3 } & SRI organik & Non SRI organik & 0,012 \\
\hline Produktivitas*** & 36,07 & 24,93 & 0,165 \\
Pendapatan atas biaya tunai* & 33,63 & 27,37 & 0,626 \\
Pendapatan atas total biaya & 31,60 & 29,40 & 0,784 \\
R/C atas biaya tunai & 31,12 & 29,88 & 0,888 \\
R/C atas total biaya & 30,82 & 30,18 & 0,00 \\
\hline
\end{tabular}

Keterangan:***,* = signifikan pada taraf nyata $5 \%$ dan $20 \%$

Sumber: Data primer (diolah)

\section{Faktor-Faktor yang mepengaruhi Penerapan Metode SRI}

Analisis faktor-faktor yang memengaruhi petani dalam penerapan metode SRI menggunakan regresi logistik (binary logit). Dalam analisis ini, Uji Wald digunakan untuk menganalisis signifikansi pengaruh masing-masing variabel independen terhadap variabel dependen. Sedangkan nilai odds ratio digunakan untuk melihat besaran pengaruh variabel independen terhadap variabel dependen. Berdasarkan Tabel 3, terdapat tujuh variabel independen yang signifikan mempengaruhi keputusan petani dalam menerapkan metode SRI yaitu usia, pendidikan, pengalaman usahatani padi, status usahatani, luas lahan, produktivitas dan pendapatan usahatani padi.

Variabel usia petani berpengaruh positif pada taraf nyata 5\% dengan nilai odds ratio sebesar 1,508. Pengaruh positif usia terhadap adopsi teknologi karena dengan semakin bertambahnya usia akan meningkatkan pengalaman dan keahlian petani sehingga berpengaruh terhadap pengambilan keputusan mengenai metode terbaik yang diterapkan pada usahataninya. Temuan ini sesuai dengan hasil penelitian Asaad, et al., (2017); Burhansyah (2014); Hendayana (2012) dan Ishak dan Afrizon (2011) yang menyatakan bahwa petani dengan usia yang lebih matang lebih mudah untuk mengadopsi teknologi baru.

Variabel pendidikan berpengaruh positif pada taraf nyata 5\% dengan nilai odds ratio sebesar 2,295. Pengaruh positif ini didasarkan pada fakta bahwa petani dengan 
pendidikan yang lebih tinggi akan memiliki pemikiran dan mental yang terbuka serta rasional sehingga lebih mudah menerima inovasi baru. Hasil ini sesuai dengan kondisi dilokasi penelitian yang menunjukkan rata-rata petani yang menerapkan metode SRI memiliki pendidikan yang lebih tinggi. Hal ini disebabkan petani dengan pendidikan lebih tinggi lebih memiliki akses terhadap infomasi mengenai dampak positif dan negatif penerapan teknologi tersebut. Temuan ini memperkuat penelitian Apriani, et al., (2018); Adrianto, et al., (2016); Nurhapsa, et al., (2014); Hendayana (2012) dan Ishak dan Afrizon (2011) yang juga menemukan pengaruh positif tingkat pendidikan terhadap adopsi teknologi.

Tabel 3. Faktor-faktor yang mempengaruhi Penerapan SRI di Desa Trasan

\begin{tabular}{lcccc}
\hline \multicolumn{1}{c}{ Variabel } & Koefisien & Sig. & Odds Ratio \\
\hline Usia & 0,411 & 0,012 & $* * *$ & 1,508 \\
Pendidikan & 0,831 & 0,005 & $* * *$ & 2,295 \\
Tanggungan keluarga & 0,142 & 0,692 & & 1,152 \\
Pengalaman usahatani padi & $-0,266$ & 0,035 & $* * *$ & 0,0766 \\
Status usahatani & 2,309 & 0,072 & $* *$ & 10,065 \\
Luas lahan & 1,022 & 0,170 & $*$ & 2,778 \\
Produktivitas & 1,737 & 0,020 & $* * *$ & 5,681 \\
Pendapatan usahatani padi & 0,142 & 0,117 & $*$ & 1,153 \\
C & $-35,033$ & 0,001 & & 0,000 \\
\hline
\end{tabular}

Keterangan:***,**,* = signifikan pada taraf nyata $5 \%, 10 \%$ dan $20 \%$

Sumber: Data primer (diolah)

Pengalaman usahatani padi berpengaruh negatif pada taraf nyata 5\% dengan nilai odds ratio sebesar 0,00766. Pengaruh negatif ini karena seiring dengan bertambahnya pengalaman yang dimiliki petani maka mereka akan semakin terbiasa melakukan teknik budidaya yang telah dilakukannya dalam waktu cukup lama sehingga diduga sulit bagi petani untuk menerima inovasi yang belum pasti tingkat keberhasilannya. Kondisi di Desa Trasan menunjukkan petani yang menerapkan metode SRI memiliki pengalaman usahatani (tahun) lebih rendah dibandingkan petani yang tidak menerapkan SRI. Temuan ini diperkuat oleh Asaad, et al., (2017) dan Hendayana (2012).

Status usahatani berpengaruh positif dan signifikan pada taraf nyata $10 \%$ dengan nilai odds ratio sebesar 10,065. Status usahatani padi sebagai sumber penghasilan utama menuntut petani untuk memilih teknik budidaya yang dapat meningkatkan produksi dan pendapatan. Upaya meningkatkan produksi tersebut dilakukan dengan menerapkan metode SRI. Kondisi tersebut sesuai dengan fakta yang menunjukkan bahwa jumlah petani SRI yang menjadikan usahatani padi sebagai sumber pengahasilan utama lebih besar dibandingkan yang tidak menerapkan metode SRI.

Luas lahan berpengaruh positif dan signfinikan pada taraf nyata $20 \%$ dengan nilai odds ratio sebesar 2,778. Temuan ini sejalan dengan hasil penelitian Adrianto, et al., (2016); Burhansyah (2014) dan Hendayana (2012) yang menyatakan bahwa peningkatan luas lahan akan meningkatkan peluang penerapan inovasi pertanian karena petani dengan 
lahan luas memiliki keadaan ekonomi yang lebih baik. Selain itu, Soekartawi (1988) menjelaskan bahwa luas lahan berpengaruh positif terhadap penerapan inovasi karena penerapan inovasi memerlukan skala operasi dan sumberdaya ekonomi yang tinggi. Kondisi di Desa Trasan menunjukkan, rata-rata luas lahan garapan petani yang menerapkan metode SRI adalah 0,66 Ha sedangkan petani yang tidak menerapkan metode SRI memiliki luas lahan garapan sebesar 0,40 Ha.

Produktivitas berpengaruh positif dan signifikan pada taraf nyata 5\% dengan nilai odds ratio sebesar 5,681. Temuan ini memperkuat hasil uji beda Mann-Whitney yang menunjukkan bahwa secara statistik terdapat perbedaan produktivitas metode SRI dengan metode non SRI. Perbedaan produktivitas tersebut meningkatkan peluang penerapan metode SRI. Produktivitas padi metode SRI yaitu sebesar 6,24 Ton/Ha/MT sedangkan metode non SRI sebesar 5,56 Ton/Ha/MT.

Pendapatan usahatani padi berpengaruh positif dan signifikan pada taraf nyata $20 \%$ dengan nilai odds ratio sebesar 1,153 . Nilai odds ratio ini berarti setiap peningkatan pendapatan usahatani padi sebesar satu juta rupiah maka akan meningkatkan peluang penerapan metode SRI sebesar 1,153 kali dari semula, ceteris paribus. Hasil ini sesuai dengan temuan Ishak dan Afrizon (2011). Soekartawi (1988) menambahkan bahwa pendapatan yang tinggi akan menyebabkan petani untuk menginvestasikan kembali modalnya untuk menerapkan kembali inovasi tersebut.

\section{SIMPULAN DAN SARAN}

\section{Simpulan}

Hasil penelitian menunjukkan bahwa total biaya usahatani padi metode SRI lebih besar dibandingkan non SRI. Selain itu, komponen biaya non tunai pada metode SRI lebih besar dibandingkan non SRI. Hal ini karena penurunan penggunaan input benih, pupuk anorganik dan TKLK dalam metode SRI dikompensasi dengan kenaikan penggunaan pupuk organik dan TKDK. Produktivitas padi metode SRI lebih besar dibandingkan non SRI sehingga metode SRI menghasilkan penerimaan yang lebih besar. Secara keseluruhan, metode SRI lebih menguntungkan dibandingkan non SRI yang terlihat dari besaran pendapatan dan nilai $\mathrm{R} / \mathrm{C}$ rasio.

Faktor-faktor yang berpengaruh positif dan signifikan terhadap peluang penerapan metode SRI yaitu usia, tingkat pendidikan, status usahatani, luas lahan garapan, produktivitas dan pendapatan usahatani. Sedangkan variabel pengalaman usahatani berpengaruh negatif dan signifikan terhadap penerapan metode SRI.

\section{Saran}

Usahatani padi dengan metode SRI terbukti mampu meningkatkan produktivitas dan pendapatan petani sehingga perlu diterapkan pada daerah lain sebagai strategi peningkatan produksi padi. Untuk mencapai hasil tersebut, pemerintah harus mendorong petani dalam mengadopsi metode SRI melalui penyuluhan dan pelatihan yang intensif. Untuk mencapai hasil yang maksimal, pemerintah harus menjamin ketersediaan input 
seperti pupuk organik yang banyak digunakan dalam metode SRI. Bagi petani, integrasi tanaman-ternak dapat menjadi alternatif dalam pemenuhan kebutuhan pupuk organik sehingga dapat mengurangi biaya usahatani dan penggunaan TKDK yang tidak optimal.

\section{DAFTAR PUSTAKA}

Adrianto, J., Harianto., Hutagaol, M.P. 2016. Peningkatan Produksi Padi melalui Penerapan SRI (System of Rice Intensification) di Kabupaten Solok Selatan. Jurnal Agribisnis Indonesia. 4(2):107-122.

Anugrah, I.S., Sumedi., dan Wardana, I.P. 2008. Gagasan dan Implementasi System of Rice Intensification (SRI) dalam Kegiatan Budidaya Padi Ekologis (BPE). Analisis Kebijakan Pertanian. 6(1):75-99.

Apriani, M., Rachmina, D., dan Rifin, A. 2018. Pengaruh Tingkat Penerapan Teknologi Pengelolaan Tanaman Terpadu (PTT) terhadap Efisiensi Teknis Usahatani Padi. Jurnal Agribisnis Indonesia. 6(2):121-132.

Asaad, M., Sugiman, S.B., dan Abidin, Z. 2017. Analisis Persepsi Petani terhadap Penerapan Tanam Jajar Legowo Padi Sawah di Sulawesi Tenggara. Jurnal Pengkajian dan Pengembangan Teknologi Pertanian. 20(3):197-208.

[BPS] Badan Pusat Statistik. 2015. Statistik Luas Baku Lahan Sawah dan Luas Panen Padi. https://www.bps.go.id.

Burhansyah, R. 2014. Faktor-Faktor yang mempengaruhi Adopsi Inovasi Pertanian pada Gapoktan PUAP dan Non PUAP di Kalimantan Barat (Studi Kasus: Kabupaten Pontianak dan Landak). Informatika Pertanian. 23(1):65-74.

Erwinata, T.L., Mustadjab, M.M., dan Syafrial. 2013. Upaya Peningkatan Pendapatan Petani dengan Menerapkan Program SRI (System of Rice Intensification) (Studi Kasus di Kecamatan Megameluh Kabupaten Jombang). AGRISE. 8(3):244-252.

Hendayana, R. 2012. Penerapan Metode Regresi Logistik dalam Menganalisis Adopsi Teknologi Pertanian. Informatika Pertanian. 22(1):1-9.

Hosmer, D.W dan Lemeshow, S. 2000. Applied Logistic Regression. New Jersey (US): John Wilet \& Sns,Inc.

Ishak, A., dan Afrizon. 2011. Persepsi dan Tingkat Inovasi Petani Padi terhadap Penerapan System of Rice Intensification (SRI) di Desa Bukit Peninjauan I, Kecamatan Sukaraja, Kabupaten Seluma. Informatika Pertanian. 20(2):76-80.

Kurniadiningsih, Y. 2012. Evaluasi Untung Rugi Penerapan Metode SRI di D.I Cihea Kabupaten Cianjur Jawa Barat [tesis]. Bogor (ID) IPB University. 
Kusnadi, N., Tinaprilla N., Susilowati, S.H., dan Purwoto, A. 2011. Analisis Efisiensi Usahatani Padi di Beberapa Sentra Produksi Padi di Indonesia. Jurnal Agro Ekonomi. 29(1):25-48.

Mulyaningsih, A. 2010. Analisis Pendapatan Usahatani Padi Organik Metode SRI (System Rice of Intensification) (Studi Kasus Desa Cipeuyeum, Kecamatan Haurwangi, Kabupaten Cianjur, Provinsi Jawa Barat) [skripsi]. Bogor (ID) IPB University.

Nurhapsa., Kusnadi, N., Firdaus, M., dan Sirajuddin, S.N. 2014. Factors Affecting Farmer's Productivity New Potato Yield Varieties. American-Eurasian Journal of Sustainable Agriculture. 8(20:52-57.

Pirngadi, K. 2009. Peran Bahan Organik dalam Peningkatan Produksi Padi Berkelanjutan Mendukung Ketahanan Pangan Nasional. Pengembangan Inovasi Pertanian. 2(1):48-59.

Saragih, B. 2011. Analisis Dampak Metode System Rice of Intensification (SRI) terhadap Penggunaan Input, Produksi dan Pendapatan Usahatani Padi Sawah di Desa Jambeneggang, Sukabumi, Jawa Barat [skripsi]. Bogor (ID) IPB University.

Soekartawi. 1988. Prinsip Dasar Komunikasi Pertanian. Jakarta (ID): UI Press.

Soekartawi. 2002. Analisis Usahatani. Jakarta (ID): UI Press.

Soekartawi., Soeharjo, A., Dillon, J.L., dan Hardaker, J.B. 2011. Ilmu Usahatani dan Penelitian untuk Pengembangan Petani Kecil. Jakarta (ID): UI Press.

Wardana, P., Juliardi, I., Sumedi.,dan Anugrah, I.S. 2005. Kajian Pengembangan System of Rice Intensification (SRI) di Indonesia. Kerjasama Yayasan Padi Indonesia dengan Badan Litbang Pertanian. Jakarta. 